Address in Portuguese and Spanish 



\section{Address in Portuguese and Spanish}

Studies in Diachrony and Diachronic Reconstruction

Edited by

Martin Hummel and Célia dos Santos Lopes

\section{DE GRUYTER}


Veröffentlicht mit Unterstützung des Austrian Science Fund (FWF): PUB 611-G30.

Gedruckt mit Unterstützung der Prof. Dr. Hugo-Schuchardt’schen Malvinenstiftung

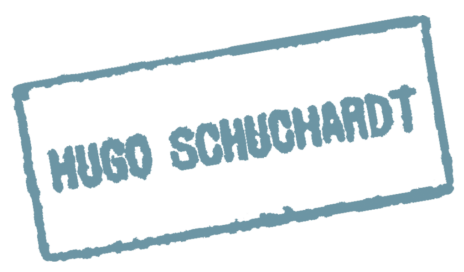

ISBN 978-3-11-069026-2

e-ISBN (PDF) 978-3-11-070123-4

e-ISBN (EPUB) 978-3-11-070185-2

DOI https://doi.org/10.1515/9783110701234

\section{(c) $\mathbf{B Y}$}

This work is licensed under a Creative Commons Attribution 4.0 International License. For details go to: https://creativecommons.org/licenses/by/4.0/.

\section{Library of Congress Control Number: 2020935642}

\section{Bibliographic information published by the Deutsche Nationalbibliothek}

The Deutsche Nationalbibliothek lists this publication in the Deutsche Nationalbibliografie; detailed bibliographic data are available on the Internet at http://dnb.dnb.de.

C 2020 Martin Hummel and Célia dos Santos Lopes, published by Walter de Gruyter GmbH, Berlin/Boston.

The book is published open access at www.degruyter.com.

Typesetting: Integra Software Services Pvt. Ltd.

Printing and binding: $\mathrm{CPI}$ books $\mathrm{GmbH}$, Leck

www.degruyter.com 